\title{
Syarifah Halimah Alaydrus
}

Mulan Jameela, 23 September 2019, mengunggah foto di akun Instagram @mulanjameela1 bersama beberapa rekan, termasuk aktris Dhini Aminarti, ketika mengikuti kajian Syarifah Halimah Alaydrus. Pada waktu itu, nama Mulan Jameela sedang menjadi 'buronan media' seiring 'pemberian gelar' baru oleh warganet, yakni label perekor (perebut kursi orang).

Unggahan tersebut tampak menjadi cara Mulan Jameela menjawab warganet yang terkesan mencibirnya setelah memenangkan gugatan hingga ditetapkan sebagai anggota DPR 20192024. 'Gelar' perekor sendiri 'diberikan' karena gugatan Mulan Jameela berdampak terhadap kegagalan Ervin Luthfi dan Fahrul Rozi menjadi anggota legislatif.

Jauh sebelum Mulan Jameela menunjukkan keterlibatan dalam kajian Syarifah Halimah Alaydrus, Reza Artamevia telah mengungkap rasa kepuasan batin. Perasaan tersebut diungkapkan Reza Artamevia setelah mengikuti kajian bertema 'Muhasabah Cinta Kehidupan Rasulullah' dari Ustazah Syarifah Halimah Alaydrus Alaydrus.

"Kepuasan batin sangat luar biasa. Majelis emang sebuah tempat barokah. Memang dianjurkan oleh Rasulullah, hadir dalam majelis pengajian dan semacamnya," kata Reza Artamevia ketika ditemui redaksi dream.co.id di Balai Kartini, Jakarta Selatan, Sabtu 3 Desember 2016.

Reza Artamevia mengaku bahwa dirinya tertarik mengikuti kajian Syarifah Halimah Alaydrus setelah diajak oleh sahabtanya, Dewi dan Rina Gunawan, 2 bulan sebelumnya. Sebagai salah satu vokalis papan atas, dalam kajian 'Muhasabah Cinta Kehidupan Rasulullah' tersebut dirinya turut memimpin lantunan 3 judul sholawat.

"Luar biasa acara Muhasabah Cinta. Tadi nangis berat dibawa untuk lebih mengenal lagi perjalanan hidup Nabi, saya merasa disini menyentuh lebih ke hati. Pendalamannya susah dijabarkan, ilmunya, unsur tasawufnya luar biasa, bukan sekedar tauhid tapi juga tasawufnya," imbuh Reza yang dikutip oleh dream.co.id.

Kajian akademik berjudul Sharifah Syarifah Halimah Alaydrus Alaydrus : a female preachers for our time yang diterbitkan melalui ResearchGate.net mengungkap bahwa Syarifah Halimah Alaydrus termasuk penceramah yang memiliki brand tersendiri. Sebagai pembicara 
untuk jemaat wanita, Syarifah Halimah Alaydrus tahu cara menyampaikan pesannya secara efektif. Beliau tahu cara berbicara dengan berbagai kalangan. Dalam satu kajian, latar belakang para jemaat bisa sangat beragam, dari ustādhāt yang memiliki majelis ta'līm (sebuah jemaat umum yang terdiri dari wanita berusia antara 40 dan 60 tahun), remaja (siswa sekolah menengah dan atas) hingga anak usia sekolah dasar.

Kekhasan ceramah Syarifah Halimah Alaydrus ialah kegemaran beliau menggunakan kisah kehidupan Nabi Muhammad dan para saḥabat sebagai bantuan penyampaian. "Cerita untuk sebagian besar jemaat perempuan saya lebih mudah dimengerti. Cerita juga bisa mencegah kebosanan. Selain itu, saya pikir ketika kita menggunakan cerita dalam ceramah kita, kita tidak hanya menyampaikan pengetahuan tetapi juga menyampaikan benih-benih cinta ke hati jemaat kita; cinta kepada Tuhan, Nabi Muhammad, dan Muslim yang saleh." Ucapnya.

Ada banyak ustādhāt yang berhasil menyampaikan pengetahuan tentang doa, seperti cara melakukannya dan unsur-unsur yang membuat doa itu dapat diterima dan tidak dapat diterima. Sayangnya, hanya ada beberapa yang dapat menyampaikan perasaan tentang cara memahami doa dan harapan orang tersebut setelah doa selesai. Syarifah Halimah Alaydrus percaya bahwa seni menyampaikan ceramah tidak hanya masalah mentransfer pengetahuan, tetapi juga mentransfer perasaan.

"Saya pikir satu poin penting dalam menyampaikan ceramah adalah tidak hanya untuk menyampaikan pengetahuan tetapi juga untuk menyentuh hati para hadirin," ucapnya, "Anda tahu, rentang usia jemaat saya beragam. Bagi saya, kisah ini terbukti lebih mudah mengakomodasi kebutuhan pertemuan ini. Saya tahu bahwa wanita dari berbagai kelompok umur suka mendengarkan ceritanya."

Soal komunikasi, Syarifah Halimah Alaydrus memang jago menjalin pembicaraan yang enak disimak telinga tanpa merisak suka. Apalagi beliau juga aktif menulis untuk menyebarluaskan ilmu dan dakwahnya. Hingga kini, Syarifah Halimah Alaydrus telah menulis empat buku: Bidadari Bumi (2010), Tutur Hati Syarifah Halimah Alaydrus Alaydrus (2014), Pilar Cahaya (2014), dan Muhasabah Cinta (2015). Belum lagi tulisan pendek yang beliau unggah melalui media sosial: Facebook, Twitter, dan Instagram; sempat aktif menulis di Blogger dan al-Kisah; sekaligus merawat akun YouTube pribadi beliau. 
Gagasan menulis buku muncul saat memikirkan orang yang ingin mendengarkan dakwahnya, tapi terkendala jarak yang jauh. Syarifah Halimah Alaydrus ingin melewati keterbatasannya dalam berdakwah. Dalam hati, beliau ingin dakwah bisa meluas. Sebab, ada banyak hal yang ingin dia bagi kepada seluruh muslimah.

Faktor lainnya, Syarifah Halimah Alaydrus tak ingin ilmu dan dakwah beliau terhenti ketika dia sudah tiada lagi di dunia. Beliau berharap, manfaat dari dakwah tersebut terus berlanjut walau sudah meninggal suatu saat nanti. Sehingga dakwah dan ilmu beliau bisa menjadi peninggalan yang baik dan bermanfaat.

Syarifah Halimah Alaydrus menyadari melalui sebuah tulisan yang tertuang dalam sebuah buku, semua itu bisa jadi solusi atas harapan yang dipendam. Apalagi Syarifah Halimah Alaydrus merupakan seorang yang memiliki hobi membaca dan menulis sejak lama. "Jadi saya berpikir, hal apa yang akan saya tulis. Saya ingin menulis sesuatu yang tidak mungkin ditulis orang lain. Tentu kisah tentang diri saya dan pengalaman sendiri," ungkapnya.

Dalam buku Bidadari Bumi, Syarifah Halimah Alaydrus menceritakan kisah para perempuan saleha yang beliau temui semasa belajar di Tarim, Hadramaut, Yaman. Beliau menulis kisah sembilan bidadari bumi yang bisa menginspirasi dan jadi teladan perempuan di zaman sekarang.

"Biasa kita dengar kisah perempuan saleha tentang Khadijah dan Aisyah, tapi kondisi mereka berbeda dengan zaman sekarang. Apa bisa kita praktikkan di kehidupan kini? Nyatanya bisa jadi saleha seperti kisah perempuan di Bidadari Bumi itu," ujarnya.

Beliau kemudian menulis tentang kisah para sahabat Rasulullah yang pertama kali masuk Islam dalam buku berjudul Pilar Cahaya. Syarifah Halimah Alaydrus merasa kisah tersebut indah untuk beliau bagi kepada umat muslim. Terakhir, buku Muhasabah Cinta yang membahas berbagai permasalahan dalam rumah tangga. "Awalnya karena saya sering dicurhat-i dan diminta nasihat soal rumah tangga. Jadi, saya pikir melalui tulisan ini mereka bisa dapat jawabannya," imbuh beliau.

Syarifah Halimah Alaydrus sendiri tumbuh dan besar di keluarga yang mementingkan agama, yakni anak kelima dari pasangan Usman Alaydrus dan Nur Assegaf. Meski ayahnya bukan seorang 'alim, tapi termasuk sosok yang sangat cinta dengan Alquran. Pria yang dia 
panggil dengan sebutan abah ini hobi membaca dan belajar memahami Alquran. Sejak Syarifah Halimah Alaydrus kecil, abah sering berkata bahwa beliau menyesal tidak belajar agama sungguh-sungguh.

"Abah bilang, urusan dunia Allah sudah atur. Tapi urusan akhirat, Alquran ini indah banget, abah sedih karena tidak mengerti," ucapnya menirukan perkataan ayahnya. Ternyata ucapan ini berdampak besar pada Syarifah Halimah Alaydrus. Setelah tamat dari bangku SD, beliau terdorong untuk mendalami agama.

Tidak hanya ayah, ibu juga melakukan hal yang sama. Perempuan yang disapanya umi ini menginginkan anak yang tidak keberatan membaca surah Yasin setiap pagi ketika dia sudah meninggal dunia. "Saya jadi tahu orangtua ingin saya seperti apa dan tujuan hidup saya. Itu terjadi sekitar kelas 5 SD, saat saya juga masih tidak tahu apa cita-cita saya," kata beliau.

Syarifah Halimah Alaydrus merealisasikan keinginan dengan mantap mulai nyantri mukim di pondok pesantren untuk mendalami agama sesuai manhaj salaf (bukan gerakan salafi). Tidak tanggung-tanggung, Syarifah Halimah Alaydrus belajar di Pesantren Darullughah Wadda'wah di Bangil, Pasuruan, Jawa Timur, yang sangat jauh dari rumah.

Beliau menyampaikan bahwa pada saat itu, tidak gampang mempertahankan semangat untuk masuk pondok pesantren. Sebab, anak yang mau sekolah pondok pesantren rerata berasal dari dua faktor. Kalau bukan karena anak nakal atau 'anak buangan' yang tidak mampu masuk sekolah negeri. "Padahal nilai akademik saya paling tinggi di sekolah. Saya sampai dipanggil pihak sekolah kenapa milih masuk pesantren. Tapi, saya tetap yakin mau sekolah di pesantren," ucap beliau mengenang.

Akhirnya petualangan mandiri Syarifah Halimah Alaydrus bermula. Perempuan yang saat itu masih berusia 12 tahun harus berpisah dengan keluarga besar di Indramayu. Beliau menghabiskan waktu lima tahun di pondok pesantren yang berlokasi di daerah Jawa Timur tersebut. Di sana, dia mulai mengenal bahwa hidup untuk Allah dan ada seorang pemimpin, yaitu Rasulullah. Beliau mulai jatuh cinta dengan ilmu agama, yakni senang belajar dan memiliki ketertarikan pada agama. "Saya ingin pelajari bagaimana kehidupan Rasulullah, saya ingin tahu bagaimana syariat Islam, atau saya ingin tahu kenapa ulama bisa berbeda pendapat. Seluruh keingintahuan itu muncul," ujarnya. 
Dari rasa keingintahuan tersebut, perjalanan mendalami ilmu agama terus berlanjut. Syarifah Halimah Alaydrus memilih fokus belajar Tauhid selama enam bulan di At Tauhidiyah Tegal. Di sana, beliau tidak hanya belajar tapi juga mulai mengajar berkat perintah pimpinan pondok pesantren. Namun, Syarifah Halimah Alaydrus menyadari bahwa beliua masih kurang ilmu ketika murid bertanya soal fikih. "Saya bilang ke kiai mau belajar lagi terutama soal ilmu fikih. Beliau rekomendasi ke Al-Anwar Rembang, saya belajar di sana tiga tahun," tutur beliau.

Perjalanannya mendalami ilmu tak juga berhenti. Ketika sudah mau tamat belajar dan mendekati waktu ujian kelulusan, abang beliau datang mengajak Syarifah Halimah Alaydrus belajar ke Tarim, Hadramaut, Yaman. Syarifah Halimah Alaydrus ingat persis, beliau bersama kakaknya berangkat menuju Yaman akhir 1998. Setelah kerusuhan dan krisis moneter yang melanda Indonesia.

Walau pada waktu itu di Tarim belum terdapat lembaga khusus perempuan, Syarifah Halimah Alaydrus tetap berangkat. "Akhirnya, abang yang belajar lalu dia rekamin, saya menulis ulang dari hasil rekaman di sekolah," imbuh beliau. Syarifah Halimah Alaydrus mengaku banyak mendapat pengalaman berharga saat bertemu dengan ulama yang menyampaikan ilmu lewat beberapa majelis karena belum ada sekolah resmi untuk perempuan.

Beruntung, seiring banyak orang berdatangan untuk mencari ilmu ke Tarim, akhirnya dibuat pondok pesantren untuk perempuan bernama Daruz Zahro. "Abang saya malah hanya tinggal 1,5 tahun, saya bertahan dan betah sampai 4,5 tahun di Hadramaut. Saya pulang sekitar 2002 dan menikah. Lalu kembali lagi setengah tahun ke sana untuk mengajar," beber beliau.

Syarifah Halimah Alaydrus benar-benar menetap kembali di Tanah Air, 2003. Hingga kini beliau aktif berdakwah, mengajar, dan bermukim di Jakarta. Sebagai ustādhāt, fokus beliau ialah ilmu Fikih yang biasa disampaikan menggunakan kisah Rasulullah. Beliau, yang memiliki penguasaan Fikih empat mazhab, melihat bahwa sekarang muslimah mulai tertarik dengan ilmu Fikih. Di luar Fikih, beliau juga melihat bahwa orang banyak tertarik dengan ilmu Tafsir. "Kalau sesama muslimah, saya cenderung dengan metode cerita lebih masuk penyampaiannya. Tema dakwah bermacam-macam dari akhlak, keluarga, keimanan, fikih, dan sebagainya," sebutnya. 
Selama belasan tahun berdakwah di Indonesia, Syarifah Halimah Alaydrus bersyukur tidak ada kendala berarti dari luar. Apalagi beliau merasa seluruh yang berada di majelis itu merupakan kawan, bukan murid. Syarifah Halimah Alaydrus berpikir semua umat Islam sama, hati mereka baik dan indah. Justru tantangan dalam berdakwah ada dalam diri beliau sendiri: agar bisa istiqomah dan tetap dakwah meski sakit atau hati sedang tidak dalam keadaan baik.

"Suami saya berpesan, selagi saya masih bisa berdiri dan bicara jangan tinggalkan majelis. Jadi, bagaimana saya bisa mengatur diri tetap bisa dakwah walau misalnya sedang sedih," ujar beliau.

Syarifah Halimah Alaydrus sering kali menjumpai momen-momen berharga yang mampu membangkitkan semangat dakwahnya. Terutama saat dakwah di daerah terpencil. Beliau bercerita, salah satu pengalamannya di Madura. Dia harus melakukan perjalanan yang cukup panjang dan melelahkan. Desa yang dituju ini masih jauh dari area kota Madura, perjalanan darat membutuhkan waktu sekitar dua jam. Pemandangan di samping kiri Laut Jawa dan samping kanan hutan belantara.

"Saya pikir siapa yang mau datang ke majelis itu. Apalagi majelis ini dilakukan malam saat mereka punya waktu luang," ungkap beliau. Namun tak disangka, mereka yang hadir jauh melebihi ekspektasi. Ribuan orang mau berkumpul dan bersama-sama melantunkan selawat. Mereka mendengarkan dakwah sampai kondisi cukup larut.

Momen seperti ini yang mampu membuat Syarifah Halimah Alaydrus terharu dan semangat berdakwah. Perempuan yang dalam kesehariannya tampil berniqab ini mengaku tak memiliki target dalam hidup. Semua dia jalani dan yakin bahwa Allah akan selalu membimbing. Dia berdoa bisa istiqomah di jalur ini.

"Selebihnya saya ingin menulis banyak hal lagi. Ini masih cari waktu dan kesempatan, semoga bisa terus konsisten menulis," kata beliau.

Dalam satu perbincangan, Syarifah Halimah Alaydrus berpesan bahwa terdapat banyak hal yang perlu disyukuri dalam hidup. Terutama nikmat Allah yang menginginkan kita sebagai hambanya. Itu kenikmatan yang tak ternilai harganya. 
"Dalam keadaan seperti apapun, ingatlah bahwa kamu punya Allah dalam hidupmu yang siap menampung segala keluh kesah, siap mendengar segala doa-doamu, dan mengijabah. Siap datang kepadamu bahkan dengan berlari, jika kamu datang kepada-Nya hanya dengan berjalan sekalipun. Jangan pernah menyerah," tutur beliau.

Beliau juga mengungkap tips bahagia ala rasulullah. Tips ini diungkap dengan menyampaikan cerita ketika ada orang yang bertanya kepada Rasulullah terkait, orang yang paling banyak mendapat nikmat. Menurut Syarifah Halimah Alaydrus, Rasulullah menjawab: Para Nabi, para Wali, para Syahid, dan orang saleh.

Syarifah Halimah Alaydrus kemudian menjelaskan bahwa pada zaman sekarang, untuk menjadi Nabi tidak mungkin karena tidak ada lagi Nabi setelah Nabi Muhammad. Untuk menjadi Wali juga ketinggian. Untuk menjadi Syahid masih mungkin karena tidak hanya orang yang pergi perang untuk membela agama Allah, tetapi orang yang bersyi'ar untuk Agama Allah yaitu ulama. "Kalau ketiganya tidak bisa, maka kejarlah untuk menjadi orang saleh, menjadi hamba Allah Ta'ala yang saleh," terang beliau.

"Siapapun yang taat kepada Allah dan Rasulullah, maka dialah orang yang dikasih nikmat paling banyak oleh Allah Ta'ala. Dialah orang yang paling bahagia. Bahagia itu adanya di hati. Tidak bisa dirasakan kulit ataupun mata. Bahagia itu tidak sebanding dengan harta, tidak sebanding dengan jabatan, tidak sebanding dengan kekayaan dan juga tidak sebanding dengan rupa." jelas beliau.

Beliau kemudian melanjutkan, "Lantas bagaimana bahagia yang sesungguhnya? Bahagia adalah orang yang hatinya dibahagiakan oleh Allah Ta'ala sebagaimana firman-Nya:

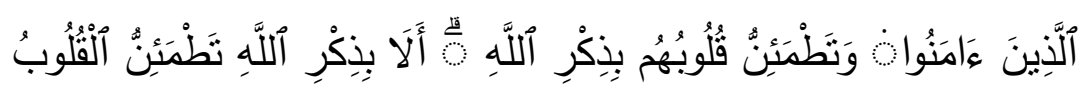

'(Yaitu) orang-orang yang beriman dan hati mereka menjadi tenteram dengan mengingat Allah. Ingatlah, hanya dengan mengingat Allah-lah hati menjadi tenteram.' Jadi selama ini mungkin kita tidak bahagia karena salah sangka dengan perspektif kebahagiaan," tutup Ustazah Syarifah Halimah Alaydrus.

$$
\text { وَاللَّهُ أعلَم بِالصََّّاب }
$$

